\title{
Hepatic Fructose-1,6-Diphosphatase Deficiency
}

\author{
A CAUSE OF LACTIC ACIDOSIS AND HYPOGLYCEMIA \\ IN INFANCY
}

\author{
Anthony S. Pagliara, Irene E. Karl, James P. Keating, \\ Barbara I. Brown, and David M. KIPNIS \\ From the Departments of Medicine, Biological Chemistry, and the Edward \\ Mallinckrodt Department of Pediatrics, Washington University School \\ of Medicine, St. Louis, Missouri 63110
}

\begin{abstract}
A B S T R A C T An 8-month-old female, maintained on breast feeding for 6 months, experienced numerous attacks of hyperventilation when weaned to baby food and was admitted with severe lactic acidosis (20 m $)$ and hypoglycemia. Physical examination was negative except for hepatomegaly. Fasting (18 hr) after stabilization on a high carbohydrate diet resulted in hypoglycemia (plasma glucose $40 \mathrm{mg} / 100 \mathrm{ml}$ ), lactic acidosis (6-10 $\mathrm{mm}$ ), and a rise in plasma alanine. Glucagon produced a glycemic response after $6 \mathrm{hr}$, but not after $18 \mathrm{hr}$ fasting. Intravenous galactose increased plasma glucose ( $\Delta 45$ $\mathrm{mg} / 100 \mathrm{ml}$ ) but intravenous fructose, glycerol, and alanine caused a $40-50 \%$ fall in plasma glucose and a significant rise in lactate $(\Delta 3-4 \mathrm{~mm})$.

Liver biopsy showed fatty infiltration. Liver slices incubated with galactose, lactate, fructose, alanine, or glycerol converted only galactose to glucose. Hepatic glycolytic intermediates were increased below the level of fructose-1,6-diphosphate and decreased above. Hepatic phosphorylase, glucose-6-phosphatase, amylo-1,6-glucosidase, phosphofructokinase, fructose-1-phosphate aldolase, and fructose-1,6-diphosphate aldolase levels were normal, but no fructose-1,6-diphosphatase (FDPase) activity was detected. Further studies on the liver homogenate of this patient revealed the presence of an acid-precipitable activator of FDPase.

Normal plasma glucose and lactate levels were maintained on an 800 cal diet of $66 \%$ carbohydrate (sucrose and fructose excluded), $5 \%$ protein, and $20 \%$ fat. When carbohydrate was reduced to $35 \%$ and protein or fat
\end{abstract}

This work was presented in part at the meeting of the American Federation for Clinical Research, Atlantic City, N. J., May 1971. (1971. Clin. Res. $19: 481$.

Received for publication 17 January 1972 and in revised form 10 March 1972. increased to 23 and $53 \%$ respectively, lactic acidosis and hypoglycemia recurred. These studies show that a deficiency of FDPase produced infantile lactic acidosis and hypoglycemia and can be controlled by an appropriate diet.

\section{INTRODUCTION}

Hepatic fructose-1,6-diphosphatase (FDPase) ${ }^{1}$ is one of the four rate-limiting enzymes in gluconeogenesis. At the present time there are two well documented disorders associated with hepatic gluconeogenic enzyme deficiencies: von Gierke's disease (absence of glucose-6-phosphatase) and the recent report by Baker and Winegrad (1) of a 5 -yr-old female with absent FDPase. While investigating an 8-month-old child with chronic lactic acidosis and fasting hypoglycemia, evidence was accumulated which implicated a defect in hepatic gluconeogenesis which could only be accounted for by a severe deficiency in the activity of FDPase. This report describes the results of gluconeogenic substrate infusion techniques which indicated the site of enzyme deficiency, and confirmation of absent FDPase activity by in vitro liver slice incubations, measurement of hepatic intermediates, and enzyme analyses. With information obtained from these studies, rational dietary therapy was instituted which has controlled the recurrence of chronic lactic acidosis and permitted normal mental and physical development.

\section{CASE REPORT}

The patient, A. W., was a full-term $7 \mathrm{lb}, 5 \mathrm{oz}$, female product of a spontaneous vaginal delivery. At 1 day of

\footnotetext{
${ }^{1}$ Abbreviations used in this paper: FDPase, fructose-1,6diphosphatase.
} 
age, hyperpnea and lethargy were noted and laboratory studies revealed a severe metabolic acidosis. The infant improved rapidly after treatment with intravenous glucose and sodium bicarbonate. During the next 6 months she exhibited normal physical and mental development on a dietary regimen of demand breast feeding and the gradual introduction of canned baby foods. She was weaned and begun on homogenized milk at the age of 7 months. Over the next 2 wk, the child exhibited repeated episodes of rapid breathing which usually appeared several hours after feeding. On one occasion, hyperpnea was extremely marked and associated with persistent vomiting which necessitated admission to a local community hospital. A severe metabolic acidosis was documented $\left(\mathrm{CO}_{2} 4.8 \mathrm{~mm}, \mathrm{pH} 6.9\right.$, and $\mathrm{Pco}_{2} 17 \mathrm{~mm}$ $\mathrm{Hg}$ ) and the patient was treated with large doses of sodium bicarbonate and intravenous glucose and transferred to St. Louis Children's Hospital.

TABLE I

Laboratory Data

$\begin{array}{ll}\begin{array}{l}\text { During episode of lactic acidosis } \\ \text { Lactic acid }\end{array} & 20 \mathrm{mM} \\ \text { Pyruvic acid } & 0.5 \mathrm{mM} \\ \mathrm{L} / \mathrm{P} & 40 \\ \mathrm{CO} & 5 \mathrm{mM} \\ \mathrm{Na} & 136 \mathrm{mEq} / \mathrm{liter} \\ \mathrm{Cl} & 97 \mathrm{mEq} / \mathrm{liter} \\ \mathrm{K} & 3.8 \mathrm{mEq} / \mathrm{liter} \\ \mathrm{Glucose} & 20 \mathrm{mg} / 100 \mathrm{ml} \\ \text { Uric acid } & 12 \mathrm{mg} / 100 \mathrm{ml} \\ \text { Cholesterol } & 188 \mathrm{mg} / 100 \mathrm{ml} \\ \text { Triglyceride } & 347 \mathrm{mg} / 100 \mathrm{ml}\end{array}$

Hematologic studies

Hemoglobin

Hematocrit

White blood cells

Platelets

Differential count

$9.5 \mathrm{~g} / 100 \mathrm{ml}$
$30 \%$
$11,000 / \mathrm{mm}^{3}$
$300,000 / \mathrm{mm}^{3}$
Normal

Liver functions

Serum glutamic oxaloacetic acid transaminase

$19 \mathrm{U}$

Serum glutamic pyruvic transaminase

$31 \mathrm{U}$

Total bilirubin

Prothrombin time

Total protein

Albumin

Globulin

$0.2 \mathrm{mg} / 100 \mathrm{ml}$

$100 \%$

$7.5 \mathrm{~g} / 100 \mathrm{ml}$

$4.0 \mathrm{~g} / 100 \mathrm{ml}$

$3.5 \mathrm{~g} / 100 \mathrm{ml}$

Renal function

Blood urea nitrogen

Creatinine

Creatinine clearance

Urine $\mathrm{pH}$

$0.67 \mathrm{mg} / 100 \mathrm{ml}$

$80 \mathrm{cc} / \mathrm{min}$ per $1.73 \mathrm{~m}^{2}$ 4.5
The child had two normal sisters. Her mother, age 28, and father, age 29, were of German-Dutch extraction, in good health, and no consanguinity could be documented.

On physical examination the patient was well developed and nourished, and in the 50th percentile for both weight and height. The only abnormal physical finding was an enlarged, smooth, nontender liver, which was palpated $6 \mathrm{~cm}$ below the right costal margin. Admission laboratory studies indicated severe lactic acidosis, hypoglycemia, hyperuricemia, and hypertriglyceridemia. Liver and renal function tests were normal (Table I).

\section{METHODS}

All studies were carried out, after first obtaining parental consent, in the Washington University Clinical Research Center in St. Louis Children's Hospital. Unless otherwise indicated, studies were performed 6-8 $\mathrm{hr}$ after the last feeding.

I. In vivo studies. The functional integrity of the glycogenolytic enzymic system was assessed by determining the glycemic response to $0.5 \mathrm{mg}$ glucagon intramuscularly after $8 \mathrm{hr}$ and $18 \mathrm{hr}$ fasts. The integrity of the gluconeogenic enzyme system was examined by determining the glycemic responses to intravenous infusions given over 5 min of $10 \%$ solutions of galactose $\left(120 \mathrm{mmoles} / \mathrm{m}^{2}\right)$, fructose $\left(60 \mathrm{mmoles} / \mathrm{m}^{2}\right)$, glycerol $\left(120 \mathrm{mmoles} / \mathrm{m}^{2}\right)$, and alanine $\left(120 \mathrm{mmoles} / \mathrm{m}^{2}\right)$, the latter being given 6 and 12 $\mathrm{hr}$ postprandially. Blood samples were obtained from an indwelling needle in the brachial vein. Plasma was separated immediately and stored at $-20^{\circ} \mathrm{C}$ for determination of plasma glucose (2), insulin (3), uric acid (4), and alanine. $^{2} 1 \mathrm{ml}$ of blood was also immediately deproteinized with an equal volume of ice-cold $3 \mathrm{~m}$ perchloric acid, the supernatant neutralized with potassium hydroxide, and stored at $-80^{\circ} \mathrm{C}$ for fluorometric determination of blood lactate (5), pyruvate (5), and $\beta$-hydroxybutyrate (6). Quantitative amino acid profiles were determined on selected plasma samples by column chromatography (7).

II. In vitro studies. After an overnight fast, an open liver biopsy under ether-nitrous oxide anesthesia was performed with the patient receiving an intravenous infusion of $5 \%$ glucose. A sample of the liver was frozen immediately in liquid nitrogen and the remainder placed in ice-cold normal saline. The frozen liver was powdered and $150 \mathrm{mg}$ homogenized in $3 \mathrm{M}$ perchloric acid employing the precautions described by Lowry et al. (5). The neutralized extract was assayed for glycolytic and Krebs cycle intermediates and adenine nucleotides, using the microfluorometric methods of Lowry and colleagues $(5,8)$.

Liver slices were prepared within $10 \mathrm{~min}$ after obtaining the biopsy with a Stadie-Riggs microtome. Two to three slices with a total wet weight of $50 \mathrm{mg}$ were distributed into $25-\mathrm{ml}$ Erlenmeyer flasks containing $2 \mathrm{ml}$ of KrebsRinger bicarbonate, $\mathrm{pH}$ 7.4, with and without added $20 \mathrm{~mm}$ gluconeogenic substrate (i.e., galactose, fructose, lactate, glycerol, and alanine). Incubations were carried out in duplicate for 90 min at $37^{\circ} \mathrm{C}$ under constant gassing with $95 \%$ $\mathrm{O}_{2}$ and $5 \% \mathrm{CO}_{2}$. At the end of the incubation, the incubation medium was assayed for glucose, lactate, and pyruvate content.

\footnotetext{
${ }^{2}$ Karl, I. E., A. S. Pagliara, and D. M. Kipnis. A specific enzymatic fluorometric assay for alanine. Manuscript in preparation.
} 


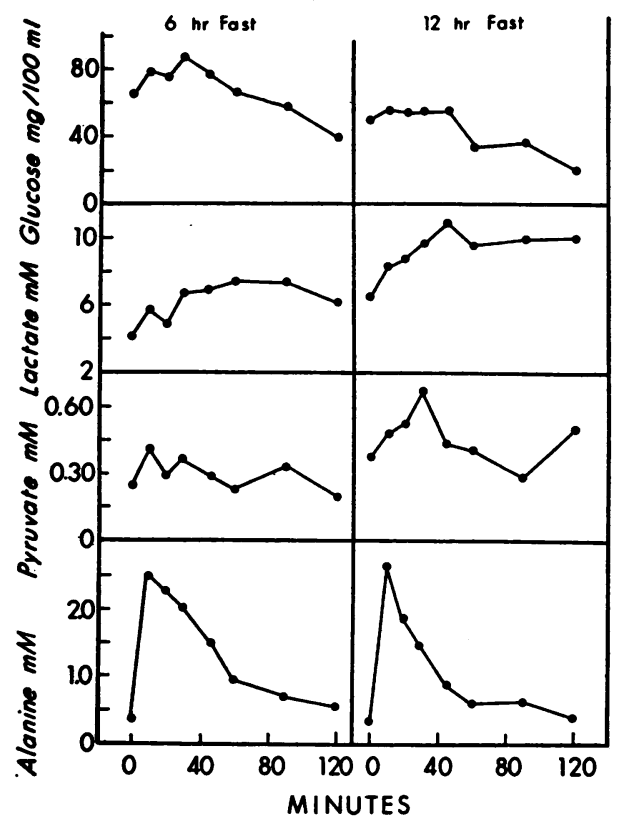

FIgURE 1 Glucagon tolerance test. Intramuscular glucagon, $0.5 \mathrm{mg}$, was given after 6- and 18-hr fasts.

The hepatic enzyme activities measured were FDPase at both 7.5 and 9.3 (9), glucose-6-phosphatase (10), phosphofructokinase (10), fructose-1-phosphate aldolase (10), fructose-1,6-diphosphate aldolase (10), phosphorylase (11), and amylo-1,6-glucosidase (12), the latter two enzymes being assayed in both the patient's liver and leukocytes. The isolation of the "natural activator" of FDPase from the patient's liver and a normal control subject was by the procedure of Pogell et al. (9).

III. Dietary studies. On a standard hospital diet $(800$ cal, $40 \%$ carbohydrate, $40 \%$ fat, and $20 \%$ protein) the patient exhibited frequent clinical and laboratory evidence of hypoglycemia and lactic acidosis. Since she was unable to tolerate a normal diet, a systematic dietary study was undertaken.

All diets contained $800 \mathrm{cal}$ and the carbohydrate in each was composed of glucose, galactose, lactose, and maltose, with negligible amounts of fructose and sucrose. The "high carbohydrate" diet contained $66 \%$ of the calories as carbohydrate and $34 \%$ as fat and protein. The "high protein" diet consisted of $23 \%$ protein, $43 \%$ fat, and $34 \%$ carbohydrate. The "high fat" diet contained $53 \%$ of the calories from fat, $12 \%$ from protein, and $35 \%$ from carbohydrate. The "therapeutic" diet, which the patient is currently receiving, consists of $56 \%$ carbohydrate, $12 \%$ protein, and $32 \%$ fat. The protein content of this diet is equivalent to $2 \mathrm{~g} / \mathrm{kg}$ body weight, adequate to meet the growth requirements of an 8-month-old child (13).

Bloods were drawn in the fasting state at 8:00 a.m. for determination of glucose, lactate, pyruvate, $\beta$-hydroxybutyrate, and uric acid. After several days on the regular hospital diet she was then placed on the high carbohydrate diet and allowed to obtain relatively normal serum bicarbonate and blood lactate concentrations. Subsequent dietary changes consisted of high protein, followed by reinstitution of high carbohydrate until normalization of blood lactate and serum bicarbonate occurred, followed by high fat and her therapeutic diet.

\section{RESULTS}

I. In vivo studies. The glycemic response of the patient to glucagon after $6 \mathrm{hr}$ and $18 \mathrm{hr}$ fasts is shown in Fig. 1. After the $6 \mathrm{hr}$ fast glucagon provoked a rise in plasma glucose from 77 to $183 \mathrm{mg} / 100 \mathrm{ml}$ within 45 $\mathrm{min}$ and a concomitant fall in blood lactate $(\Delta-1.7 \mathrm{~mm})$ and pyruvate $(\Delta-0.15 \mathrm{~mm})$. After an $18 \mathrm{hr}$ fast no significant change in plasma glucose was noted although both blood lactate $(\Delta 2.5 \mathrm{~mm})$ and pyruvate $(\Delta 0.15 \mathrm{~mm})$ increased.

The patient's response to the intravenous administration of alanine after 6 and $12 \mathrm{hr}$ fasts is shown in Fig. 2. In the early postabsorptive state, alanine produced a prompt and modest increase in plasma glucose from 64 to $86 \mathrm{mg} / 100 \mathrm{ml}$ which then fell progressively to 40 $\mathrm{mg} / 100 \mathrm{ml}$ after $2 \mathrm{hr}$. During this period, blood lactate increased from an initial value of $4.0 \mathrm{~mm}$ to $6.8 \mathrm{~mm}$. After a $12 \mathrm{hr}$ fast, alanine administration did not provoke a glycemic response; the plasma glucose concentrations remained at $50 \mathrm{mg} / 100 \mathrm{ml}$ for the first $60 \mathrm{~min}$ and then fell progressively to $23 \mathrm{mg} / 100 \mathrm{ml}$ by $120 \mathrm{~min}$. Plasma lactate increased from 6.0 to $10.5 \mathrm{~mm}$. Plasma alanine concentrations during these studies are also shown in Fig. 2. The patient's fasting alanine after 6 and $12 \mathrm{hr}$ fasts remained at 400 and $410 \mu_{\mathrm{M}}$ respectively; both values were significantly greater than that found in normal children after an overnight fast $\left(296 \pm 25 \mu_{\mathrm{M}}\right)$.

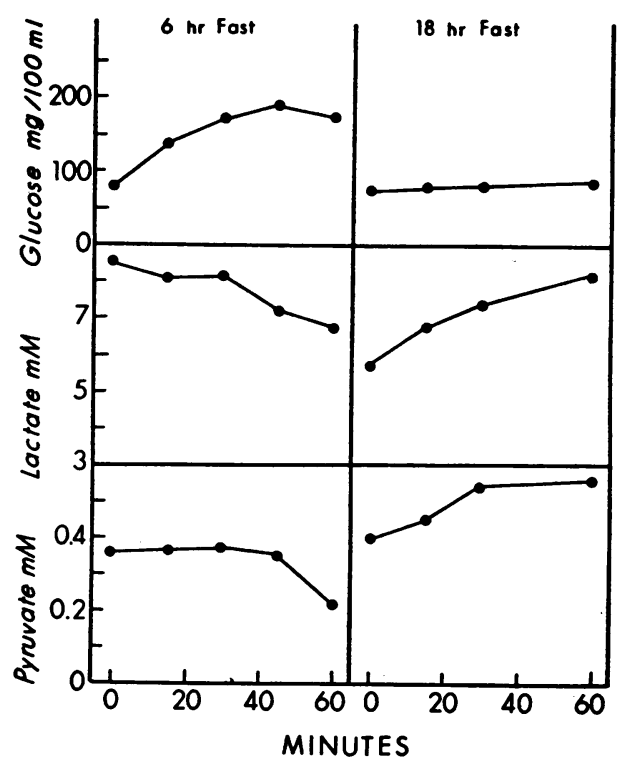

Figure 2 Response to alanine. Intravenous alanine, 120 $\mathrm{mmoles} / \mathrm{m}^{2}$ body surface area was administered over a 5 min period after 6 - and $12-\mathrm{hr}$ fasts. 


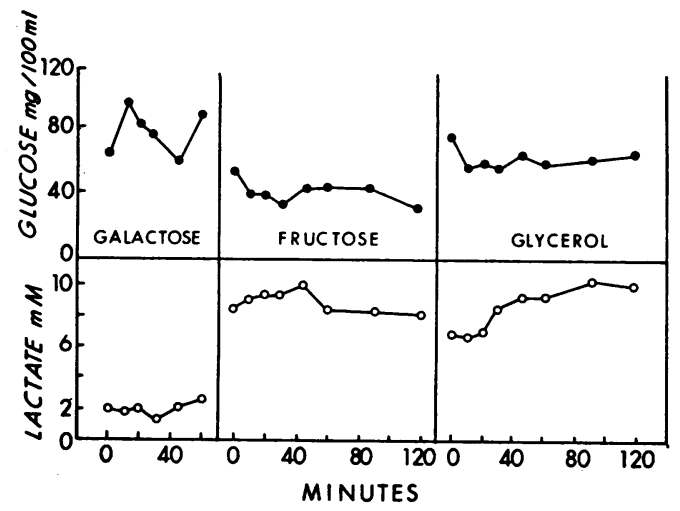

FIGURE 3 Response to intravenous administration of galactose, $120 \mathrm{mmoles} / \mathrm{m}^{2}$; fructose, $60 \mathrm{mmoles} / \mathrm{m}^{2}$; and glycerol, $120 \mathrm{mmoles} / \mathrm{m}^{2}$ body surface area.

The patient's response to galactose, fructose, and glycerol infusions is shown in Fig. 3. Galactose infusion produced a prompt increase in the patient's plasma glucose with no detectable change in blood lactate. Both fructose and glycerol, however, caused a rapid fall in plasma glucose and a concomitant increase in blood lactate, 2-3 $\mathrm{mm}$ above base line levels.

II. In vitro studies. The concentrations of the various intermediates found in the liver are shown in Table II. Since normal concentrations of human intermediates are not known, the values are compared with those from normal rats in our laboratory. Livers from six animals fasted overnight were removed under ether anesthesia and frozen rapidly in liquid nitrogen. Both fructose-6phosphate and glucose-6-phosphate were decreased in the liver of the patient, whereas the normal 10:1 ratio between these two intermediates was maintained. There was an increase in hepatic fructose-1,6-diphosphate, dihydroxyacetone phosphate, and $\alpha$-glycerophosphate. The normal ratio of $\alpha$-glycerophosphate to dihydroxyacetone phosphate is approximately $8-10$ in the rat (14). In our patient a ratio of 260 was found. Marked differences in the lactate-pyruvate ratios between the two species were also apparent. The rat livers demonstrated a normal ratio of 17.5 (14), while that of the patient was 206 . The malate concentration was $897 \mu$ moles $/ \mathrm{kg}$ as compared with $388 \mu$ moles $/ \mathrm{kg}$ in the rat. Oxalacetate was too low to be detected in the patient's liver. Since the reaction of malate to oxalacetate is a nicotinamide-adenine dinucleotide (NAD)-reduced NAD (NADH) couple as is lactate-pyruvate and $\alpha$-glycerophosphate-dihydroxyacetone phosphate, concentrations of oxalacetate would be low and the ratio of malate to oxalacetate elevated. Concentrations of pyruvate, phosphoenolpyruvate, $\alpha$-ketoglutarate, and citrate were decreased in the patient's liver as compared with the rat; this was also a reflection of the abnormal redox state.
The concentrations of the purine nucleotides (i.e. adenosine triphosphate [ATP], adenosine diphosphate [ADP], and adenosine monophosphate [AMP]) were similar in the two species (Table II) making it unlikely that anoxic changes in the patient's liver before analysis could account for the differences observed (15). The liver biopsy in our patient was performed under ideal conditions consisting of intravenous glucose infusion to maintain plasma glucose normal $(80-95 \mathrm{mg} / 100$ $\mathrm{ml}$ ) and prevent lactic acidosis (blood lactates 2-2.5 $\mathrm{mm})$. Thus, the abnormal concentrations of hepatic intermediates observed in all likelihood were minimal. Under conditions of active gluconeogenesis, it is possible that these abnormalities would be much more accentuated.

The results of the incubation of liver slices with various substrates is illustrated in Fig. 4. There was a marked increase in glucose production from galactose (150-530 $\mathrm{m} \mu_{\mathrm{M}} / 50 \mathrm{mg}$ liver). There was no increase in glucose production from fructose, glycerol, lactate, or alanine; however, there was a $75 \%$ increase over the controls in lactate production from galactose, glycerol, and alanine. Pyruvate production was similar with all the substrates except alanine in which there was a 10 -fold increase.

Normal levels of glucose-6-phosphatase, phosphorylase, and phosphofructokinase were found in the liver (Table III). The level of fructose-1,6-diphosphate aldolase was $5 \mu \mathrm{mole} / \mathrm{min}$ per $\mathrm{g}$ liver and fructose-1-phosphate aldolase was $3.3 \mu \mathrm{moles} / \mathrm{min}$ per $\mathrm{g}$ liver, both activities being in the normal range reported for human liver (16). Furthermore, the ratio of 1.5 for fructose-1,6-diphosphate aldolase to fructose-1-phosphate aldolase was also normal

TABLE II

Concentrations of Hepatic Intermediates

\begin{tabular}{|c|c|c|c|}
\hline & Patient & Rat* & $\begin{array}{l}\text { Per cent of } \\
\text { patient/rat }\end{array}$ \\
\hline & \multicolumn{2}{|c|}{$\mu$ moles $/ \mathrm{kg}$ liver } & \\
\hline \multicolumn{4}{|l|}{ Glycolytic } \\
\hline Glucose-6-phosphate & 119.5 & $273.0 \pm 29.5$ & 44 \\
\hline Fructose-6-phosphate & 11.4 & $27.0 \pm 1.8$ & 42 \\
\hline Fructose-1, 6-diphosphate & 43.7 & $25.0 \pm 2.2$ & 175 \\
\hline Dihydroxyacetone phosphate & 39.1 & $27.5 \pm 1.8$ & 170 \\
\hline$\alpha$-Glycerophosphate & 1012.5 & $206.8 \pm 15.4$ & 490 \\
\hline Phosphoenolpyruvate & 47.2 & $65.7 \pm 4.4$ & 72 \\
\hline Pyruvate & 14.5 & $106.0 \pm 6.9$ & 7 \\
\hline Lactate & 2980.0 & $1820.0 \pm 160.0$ & 164 \\
\hline \multicolumn{4}{|l|}{ Krebs cycle } \\
\hline$\alpha$-Ketoglutarate & 29.2 & $113.0 \pm 10.6$ & 39 \\
\hline Citrate & 165.5 & $194.0 \pm 12.2$ & 85 \\
\hline Malate & 897.0 & $388.0 \pm 25.5$ & 222 \\
\hline \multicolumn{4}{|l|}{ Adenine nucleotides } \\
\hline ATP & 2200.0 & $2730.0 \pm 54.0$ & 80 \\
\hline ADP & 1004.0 & $765.0 \pm 45.0$ & 132 \\
\hline AMP & 180.8 & $139.0 \pm 9.6$ & 130 \\
\hline
\end{tabular}

* Each intermediate represents the mean 士SEM of six animals. 


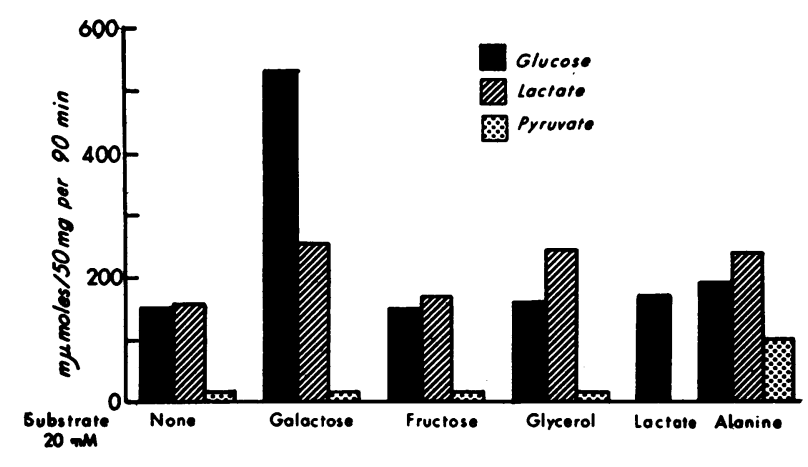

Figure 4 Results of incubation of liver slices without added substrate and in the presence of $20 \mathrm{~mm}$ galactose, fructose, glycerol, lactate, and alanine.

(16). Phosphorylase and amylo-1,6-glucosidase assays were performed on the patient's leukocytes (Table III). The levels of both enzymes in this patient were normal.

FDPase was assayed at $\mathrm{pH} 7.5$ and 9.3 (Table IV). A control liver with known FDPase activity was assayed simultaneously. The patient's liver had less than $4 \%$ of the enzyme activity found in the normal liver. To exclude the possibility of an inhibitor of FDPase activity, equal portions of the supernatant fraction of the patient's liver were-added to that of a normal control. No evidence of inhibition was observed. Instead, at $\mathrm{pH} 7.5$ (Table IV), there was noted a $70 \%$ increase in activity over that expected by adding the individual activities of both livers. No activation occurred at $\mathrm{pH}$ 9.3. AMP (a known inhibitor of rabbit liver FDPase [9]), in concentrations between $0.5-1.0 \mathrm{~mm}$, produced a $50 \%$ inhibition in the FDPase activity of normal liver; however, there was no further decrease in the activity of this enzyme in the patient's liver.

When an extract of normal liver heated to $80^{\circ} \mathrm{C}$ for $10 \mathrm{~min}$ was added to the patient's liver, no increase in activity occurred. When the normal liver was dialyzed and the patient's liver homogenate added to the dialyzate, activation occurred that was only slightly less than that of undialyzed liver. Neither cysteine, cysteamine, cystine, or cystamine increased the enzyme activity of the patient's liver. Cystamine, a known activator of rabbit liver FDPase at neutral $\mathrm{pH}(17)$, however, increased the enzyme activity of normal liver by $86 \%$ (Table IV).

Pogell et al. (9) have shown that rabbit muscle phosphofructokinase is an activator of rabbit liver FDPase. When purified rabbit muscle phosphofructokinase (Boehringer Mannheim Corp., New York) was added to both the normal and patient's liver homogenate there was no increased activity. A pH 5.2 fraction of both the normal and patient's livers was made in order to precipitate the natural activator of liver FDPase (9). When the $\mathrm{pH}$ 5.2 fraction from normal liver was added to the supernatant of the patient's liver, no increase in FDPase ac-
TABLE III

Enzyme Determinations

\begin{tabular}{|c|c|c|}
\hline & Normals & Patient \\
\hline 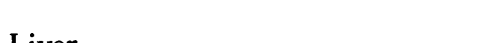 & \multicolumn{2}{|c|}{ umoles $/$ min per $\mathrm{g}$ wel $w$} \\
\hline $\begin{array}{l}\text { Liver } \\
\text { Fructose-1, 6-diphosphatase }\end{array}$ & $\begin{array}{c}1.9-5.6^{*} \\
(7)\end{array}$ & $0.08-0.117$ \\
\hline Glucose-6-phosphatase & $\begin{array}{c}10-25 \\
(7)\end{array}$ & 21 \\
\hline Fructose-1, 6-diphosphate aldolase & $\begin{array}{l}5.8 \\
(1)\end{array}$ & 5.0 \\
\hline Fructose-1-phosphate aldolase & $\begin{array}{l}3.7 \\
(1)\end{array}$ & 3.3 \\
\hline Phosphofructokinase & $\begin{array}{l}6.5 \\
(1)\end{array}$ & 4.4 \\
\hline \multicolumn{3}{|c|}{ mumoles/min per mg proteir } \\
\hline Phosphorylase & $\begin{array}{c}20-38 \\
(9)\end{array}$ & 21 \\
\hline Amylo-1, 6-glucosidase & $\begin{array}{c}0.31-1.1 \\
(7)\end{array}$ & 0.35 \\
\hline
\end{tabular}

* Range of enzyme activity and total number of patients having determinations.

tivity was noted; however, when the same fraction from the patient's liver was added to the normal liver homogenate, an increase in enzyme activity of $130 \%$ occurred.

\section{TABLE IV}

FDPase Activity in Liver and Muscle of $A . W$. and Normal Subject; Effects of $p H$, Mixing, Heating, $A M P$, Dialysis, Crystamine, pH 5.2 Fraction and Purified Muscle Phosphofructokinase $(P F K) *$

\begin{tabular}{|c|c|c|c|}
\hline Treatment of liver of patient and normal & $\mathrm{pH} 7.5$ & pH 9.3 & $\begin{array}{c}\text { Per cent of } \\
\text { normal at } \\
\text { pH } 7.4\end{array}$ \\
\hline & \multicolumn{2}{|c|}{$\mu$ moles $/ \mathrm{g}$ per $\min$} & \\
\hline Normal & 4.20 & 5.80 & - \\
\hline Patient & 0.12 & 0.18 & 3 \\
\hline Patient + normal & 7.20 & 5.80 & 172 \\
\hline Normal + AMP, $5 \times 10^{-1} \mathrm{M}$ & 2.15 & & 50 \\
\hline Patient + AMP, $5 \times 10^{-4} \mathrm{M}$ & 0.11 & & 3 \\
\hline Patient + heated normal & 0.10 & & 3 \\
\hline Normal + heated patient & 4.00 & & 96 \\
\hline Patient + dialyzed normal & 6.80 & & 162 \\
\hline Normal + dialyzed patient & 6.90 & & 165 \\
\hline Patient $+1 \times 10^{-4} \mathrm{M}$ cystamine & 0.10 & & 3 \\
\hline Normal $+1 \times 10^{-1} \mathrm{M}$ cystamine & 7.80 & & 186 \\
\hline Patient + muscle PFK & 0.09 & & 2 \\
\hline Normal + muscle PFK & 4.00 & & 96 \\
\hline Patient + pH 5.2 precipitate of normal liver & 0.10 & & 3 \\
\hline Normal $+\mathrm{pH} 5.2$ precipitate of patient liver & 9.70 & & 230 \\
\hline Normal muscle & 0.115 & & - \\
\hline Normal muscle + AMP $5 \times 10^{-4} \mathrm{M}$ & 0.060 & & 48 \\
\hline Patient muscle & 0.110 & & - \\
\hline Patient muscle + AMP $5 \times 10^{-4} \mathrm{M}$ & 0.055 & & 50 \\
\hline
\end{tabular}

* All analyses and preparations except for cystamine were carried out as described by Pogell et al. (9). For the cystamine study the protocol of Pontremali et al. (17) was used. 
It was therefore concluded that the patient had sufficient activator, but lacked the presence of hepatic FDPase (Table IV).

Skeletal muscle FDPase was also assayed in both a normal subject and the patient. There was no difference in activity between the two specimens and both activities were decreased on addition of AMP (Table IV).

III. Family studies. The mother, father, and two older sisters, aged 5 and 7 , were admitted to the Clinical Research Unit and intravenous fructose and glycerol tolerance tests were performed after a $12 \mathrm{hr}$ overnight fast. In all family members, the infusion of these two substrates provoked an increase in plasma glucose and transient rise in blood lactate within the first $10 \mathrm{~min}$; the lactate never exceeded $2.2 \mathrm{~mm}$.

IV. Dietary studies. The results of the dietary study are illustrated in Fig. 5. On the routine hospital diet the patient demonstrated relatively low fasting plasma glucose along with elevated blood lactate and $\beta$-hydroxybutyrate concentrations. On institution of the high carbohydrate diet all these values returned to normal (days $3-6)$. On the high protein diet blood lactates increased $(2.0-6.3 \mathrm{~mm})$, with a concomitant fall in serum bicarbonate (days 6-8). Reinstitution of the high carbohydrate diet corrected the metabolic defects (days 8-12). On the high fat diet severe lactic acidosis, hypoglycemia, and ketonemia rapidly developed (days 12-14). When switched to the therapeutic diet these changes rapidly reversed (days 15-17) (Fig. 5). In all of these studies plasma glucose concentrations were inversely correlated with blood lactate, while blood lactate and plasma uric acid demonstrated a direct linear relationship (Fig. 6).

Quantitative fasting plasma amino acid profiles by column chromatography were obtained on the patient during two episodes of severe lactic acidosis. These are compared in Table $\mathrm{V}$ with those of nine normal children

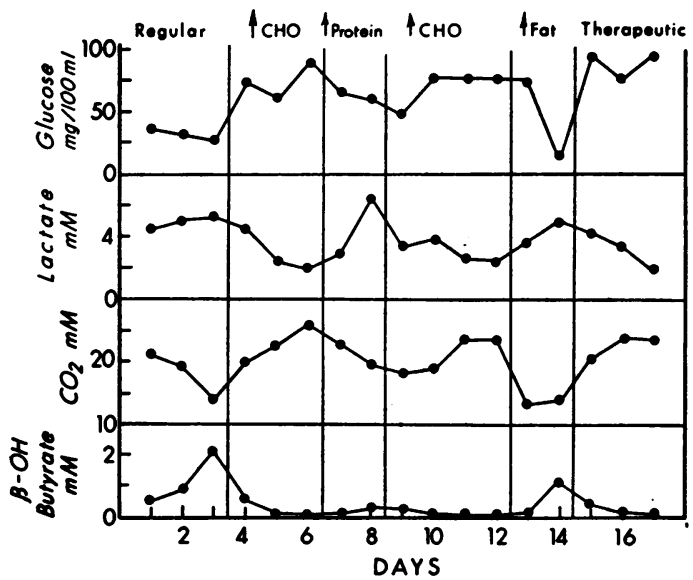

Figure 5 Results of dietary study. Changes in the patient's diet were made at 8 a.m. represented by the vertical lines.

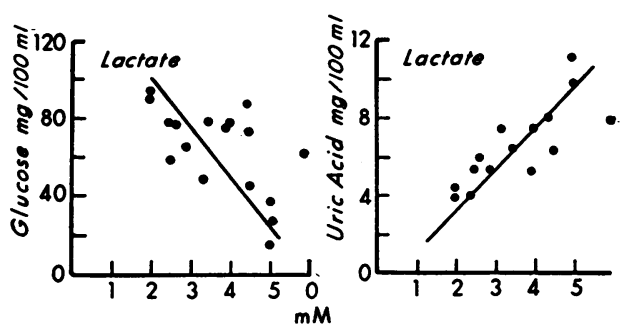

Figure 6 Relationships of plasma glucose to blood lactate levels and plasma uric acid to blood lactate during the dietary study.

after an overnight fast. The most striking finding is the two- to threefold elevation of plasma alanine together with elevations of threonine, serine, proline, and tyrosine, other gluconeogenic amino acids.

\section{DISCUSSION}

FDPase is one of the four rate-limiting enzymes necessary for glucose production from fructose, lactate, glycerol, and the gluconeogenic amino acids (18). With the absence of this enzyme, fasting hypoglycemia and severe lactic acidosis would be expected. Furthermore, a deficiency of this enzyme would also account for marked elevation of the gluconeogenic amino acids (Table V), in particular alanine which is considered to be the most important amino acid for gluconeogenesis (19).

The chronic lactic acidosis seen in this patient is directly due to an inability of the liver to convert the above-mentioned substrates to glucose leading to an accumulation of both lactate and pyruvate. The markedly reduced state of the NAD-NADH couples lactate-pyruvate and $\alpha$-glycerophosphate-dihydroxyacetone phosphate in the liver are due to the absence of FDPase, resulting in accumulation of the precursor glyceraldehyde-3-phosphate, a step at which $\mathrm{NADH}$ is reoxidized to NAD (20) (Fig. 7).

The above conclusion is further supported by the in vivo infusions of fructose, glycerol, and alanine. The response to intravenous infusions of these substrates in children with a normal hepatic gluconeogenic enzymic system is an increase in the plasma glucose, without accumulation of lactic acid (21-23). As illustrated in Figs. 2 and 3 , infusions of these normally gluconeogenic substrates in our patient were followed by a rapid accumulation of lactic acid. Further, with fructose and glycerol, as well as alanine after a $12 \mathrm{hr}$ fast, the concentration of plasma glucose fell to hypoglycemic levels. Plasma insulin concentrations could not account for the decrease in plasma glucose as they were appropriately low for the degree of glycemia on all occasions $(<5 \mu$ units $/ \mathrm{ml})$.

Similar data have been presented by Baker and Winegrad (1) in the first reported case of FDPase deficiency. In their child, oral fructose and glycerol ad- 
ministration resulted in a rapid fall in plasma glucose. In hereditary fructose intolerance in which there is an absence of the enzyme fructose-1-phosphate aldolase, intravenous infusion or oral ingestion of fructose leads to a rapid fall in plasma glucose (24). The acute hypoglycemia after fructose infusion is felt to be due to accumulation of the intermediate fructose-1-phosphate which blocks glycogenolysis by inhibiting hepatic phosphorylase (24). In the absence of FDPase a rapid accumulation of the triose phosphates could in a similar fashion act as product inhibitors of hepatic phosphorylase and lead to inhibition of glycogenolysis with resultant hypoglycemia.

Infusions of alanine after 6 and $12 \mathrm{hr}$ fasts resulted in divergent glucose responses (Fig. 2). After the $6 \mathrm{hr}$ fast there was a transient increase in plasma glucose within the first $30 \mathrm{~min}$, with a subsequent fall to hypoglycemic levels. After the patient had been fasted for $12 \mathrm{hr}$, there was no increase in plasma glucose over the first $60 \mathrm{~min}$, with a subsequent fall to $22 \mathrm{mg} / 100 \mathrm{ml}$ by $120 \mathrm{~min}$. With both infusions there was a sustained rise in blood lactate and pyruvate. The differences between the two tests are interesting in the light of the recent observations of Muller et al. (25) that the amino acid alanine is a potent stimulator of pancreatic glucagon. After a relatively short fast, the rise in plasma glucose could be explained by glycogen release from the liver mediated by pancreatic glucagon. Conversely, with a longer fast when liver glycogen stores are depleted, alanine can be converted only to the level of fructose-1,6diphosphate and triose phosphates, with resultant hypoglycemia secondary to deficient gluconeogenesis.

TABLE V

Plasma Amino Acid Profiles on A. W. and Nine Children after an Overnight Fast

\begin{tabular}{lccc}
\hline \multicolumn{1}{c}{ Amino acid } & Controls* & A. W. 1f & A. W. 2t \\
\hline Threonine & $152 \pm 20$ & 412 & 396 \\
Serine & $168 \pm 11$ & 218 & 182 \\
Proline & $140 \pm 18$ & 204 & 207 \\
Glycine & $238 \pm 8$ & 300 & 246 \\
Alanine & $296 \pm 25$ & 750 & 980 \\
Valine & $177 \pm 10$ & 290 & 220 \\
Isoleucine & $71 \pm 7$ & 91 & 67 \\
Leucine & $175 \pm 8$ & 162 & 86 \\
Tyrosine & $69 \pm 7$ & 100 & 124 \\
Phenylalanine & $64 \pm 4$ & 73 & 43 \\
Lysine & $240 \pm 41$ & 306 & 225 \\
Histidine & $132 \pm 19$ & 65 & 90 \\
Arginine & $79 \pm 1$ & 51 & 93 \\
\hline
\end{tabular}

* Values represent mean \pm SEM and are expressed as micromoles per liter.

‡ Plasma for both amino acid profiles were obtained on two separate occasions when the patient was in severe lactic acidosis.
In contrast to the other gluconeogenic substrates galactose infusion resulted in a rapid increase in plasma glucose (Fig. 3). Since galactose enters the EmbdenMyerhoff pathway at glucose-1-phosphate (Fig. 7), utilization of this substrate would be expected. The patient reported by Baker and Winegrad (1) also responded normally to a galactose challenge. $42 \%$ of the total calories derived from breast milk are provided in the form of lactose (13) which may account for the lack of symptoms during the first 6 months of life.

Glucagon administered after 6 and $18 \mathrm{hr}$ fasts produced divergent results (Fig. 1). In the postabsorptive state glucagon is a potent glycogenolytic hormone and insulinogenic secretogogue. After a fast when hepatic glycogen stores are depleted glucagon does not stimulate insulin release (21). Although plasma insulin concentrations were not determined during the two glucagon studies, the decrease in blood lactate and pyruvate after the $6 \mathrm{hr}$ fast may have been mediated by increased concentrations of circulating insulin, resulting in decreased hepatic extraction of gluconeogenic substrates (26) and decreased peripheral tissue mobilization (27). The lack of a glycemic response with an increase in blood lactate and pyruvate after the $18 \mathrm{hr}$ fast was a reflection of hepatic glycogen depletion and possibly glucagon's effect on increasing hepatic transamination and utilization of alanine (28).

The activity of the enzyme FDPase was investigated by assessing in vitro hepatic gluconeogenesis from various substrates, measuring metabolic intermediates, and assaying directly for FDPase activity. All studies performed on the biopsied liver indicated little or no activity of this enzyme. The results of incubating liver slices with gluconeogenic substrates were consistent with the in vivo infusion studies and indicated that the liver was capable of converting only galactose to glucose. Steady-state concentrations of hepatic intermediates in normal human liver are not known and therefore the results were compared with those of rat liver. Although it is not entirely justifiable to compare individual concentrations between the two species, the general pattern of elevated intermediates below FDPase, with a decrease in concentrations above this enzyme, are in accord with the other data obtained implicating a deficiency of FDPase. The activity of FDPase in this patient was approximately $3 \%$ of the control value. All other liver enzymes assayed (Table III) were well within the normal range.

FDPase in rabbit liver assayed at neutral $\mathrm{pH}$ has been shown to be activated and deactivated by various substances. Activators of this enzyme are cystamine (17), muscle phosphofructokinase, and a heat-inactivated, nondialyzable fraction of liver which can be precipitated at acid $\mathrm{pH}$ (9). This fraction is felt to be the natural 


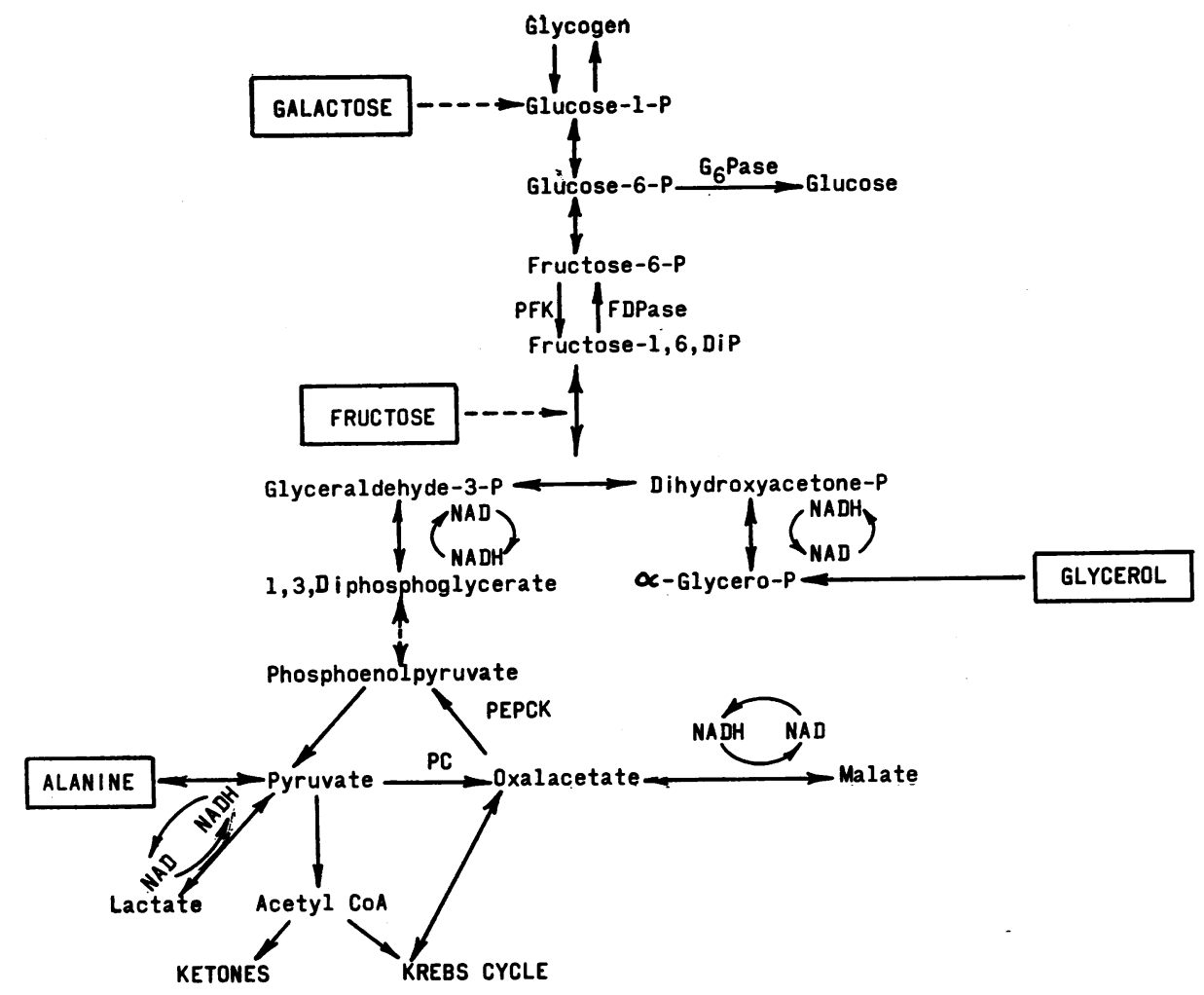

FIGURE 7 Schematic diagram of the gluconeogenic pathway. G ${ }_{8}$ Pase, glucose-6-phosphatase ; FDPase, fructose-1,6-diphosphatase ; PFK, phosphofructokinase; PC, pyruvate carboxylase ; PEPCK, phosphoenolpyruvate carboxykinase.

activator of hepatic FDPase (9). AMP is an inhibitor of FDPase (9). Assays for FDPase at $\mathrm{pH} 7.5$ and 9.3 in our patient gave negligible enzyme activities, and there was no further decrease on addition of AMP, suggesting that the small amount of enzyme activity present was due to nonspecific phosphatases. The possibility that an inhibitor accounted for the absent activity of FDPase was ruled out when addition of the patient's liver homogenate to the normal resulted in $70 \%$ greater enzyme activity than the sum of the two separate activities. Addition of cystamine to the normal liver resulted in increased enzyme activity, similar to that found with rabbit FDPase (17), but cystamine had no effect on the patient's liver homogenate, further evidence that nonspecific phosphatase was accounting for the small enzyme activity present. Preparation of a $\mathrm{pH} 5.2$ fraction from the liver of the patient and control demonstrated that an activator was present in both, and that the absent FDPase activity in the patient's liver is, in fact, due to the absence of the enzyme and not the activator (Table V).

Muscle FDPase was present in the patient. The absence of this enzyme in the liver, with its presence in muscle, suggests that the two enzymes are genetically distinct, analogous to that found with muscle and hepatic FDPase of rabbit (29).

Intravenous fructose and glycerol were administered to the patient's parents and two siblings. All family members responded normally to both substrates. If a heterozygous state in this disorder exists it cannot be detected by substrate infusions in the dose range studied.

Various isocaloric dietary regimens demonstrated that the patient was unable to properly utilize calories derived from protein, fat, or fructose-containing carbohydrates. By modification of her diet so that $56 \%$ of her calories were derived from carbohydrate in the form of glucose, galactose, lactose, and maltose, the lactic acidosis rapidly cleared.

During the dietary study it was demonstrated that an inverse correlation existed between plasma glucose and blood lactate while a direct correlation was apparent between blood lactate and serum uric acid (Fig. 6). The concomitant rise and fall of uric acid and lactate is ascribable to the fact that they are regulated by the same renal tubular secretory mechanism (30).

The patient has been followed for the past 15 months, being maintained on the prescribed diet. Growth and development have been normal. Euglycemia and acid- 
base balance have been maintained; however, with intercurrent infections associated with fever and vomiting, she has developed lactic acidosis (blood lactate 17-20 $\mathrm{mm}$ ) and hypoglycemia (plasma glucose less than 20 $\mathrm{mg} / 100 \mathrm{ml}$ ) on two occasions since her initial evaluation. Both episodes were rapidly corrected with intravenous glucose, neither episode requiring bicarbonate administration.

\section{ACKNOWLEDGMENTS}

We wish to thank Mrs. Barbara Till for her help and suggestions in the dietary therapy of this patient and $\mathrm{Mr}$. Thomas Howard for his excellent technical assistance.

Dr. Pagliara performed his work during tenure as a Daland Fellow of the American Philosophical Society and under U. S. Public Health Service Training Grant No. 5T1-AM 5027-14.

This research was supported by Research Grants AM01921-14, GM-04761, and Research Center Grant RR00036, St. Louis Children's Hospital, from the National Institutes of Health.

\section{REFERENCES}

1. Baker, L., and A. I. Winegrad. 1970. Fasting hypoglycemia and metabolic acidosis associated with deficiency of hepatic fructose-1, 6-diphosphatase activity. Lancet. 2: 13 .

2. Huggett, A. St. G., and D. A. Nixon. 1957. Use of glucose oxidase, peroxidase and $o$ dianisidine in determination of blood and urinary glucose. Lancet. 2: 368.

3. Morgan, C. A., and A. Lazarow. 1963. Immunoassay of insulin. Diabetes. 12 : 115.

4. Liddle, L., J. E. Seegmiller, and L. Laster. 1959. The enzymatic spectrophotometric method for determination of uric acid. J. Lab. Clin. Med. 54: 903.

5. Lowry, O. H., J. V. Passonneau, F. X. Hesselberger, and D. W. Schulz. 1964. Effect of ischemia on known substrates and co-factors on the glycolytic pathway in brain. J. Biol. Chem. 239: 18.

6. Cahill, G. F., Jr., M. G. Herrera, A. P. Morgan, J. S. Soeldner, J. Steinke, P. L. Levy, G. A. Reichard, Jr., and D. M. Kipnis. 1966. Hormonal-fuel interrelationships during fasting. J. Clin. Invest. 45: 1751.

7. Technicon Autoanalyzer Methodology, Technicon Chromatography Corp., Technicon Co., Inc., Copyright 1960, Tarrytown, N. Y.

8. Goldberg, N. D., J. V. Passonneau, and O. H. Lowry. 1966. Effects of changes in brain metabolism on the levels of citric acid cycle intermediates. J. Biol. Chem. $241: 3997$.

9. Pogell, B. M., A. Tanaka, and R. C. Siddons. 1968. Natural activators for fructose-1,6-diphosphatase and reversal of adenosine 5-monophosphate inhibition by muscle phosphofructokinase. J. Biol. Chem. 243: 1356.

10. Burch, H. B., O. H. Lowry, A. M. Kuhlman, J. Skerjance, E. J. Diamant, S. R. Lowry, and P. Von Dippe. 1963. Changes in patterns of enzymes of carbohydrate metabolism in the developing rat liver. J. Biol. Chem. 238: 2267.

11. Cori, G. T., B. Illingworth, and P. J. Keller. 1955. Muscle phosphorylase. In Methods in Enzymology. S. P. Colowick and N. O. Kaplan, editors. Academic Press, Inc., N. Y. $1: 200$.

12. Cori, G. T. 1955. Amylo-1,6-glucosidase. In Methods in
Enzymology. S. P. Colowick and N. O. Kaplan, editors. Academic Press, Inc., New York. 1 : 211.

13. Nitowsky, H. M. 1968. The anabolic and catabolic systems. In The Biologic Basis of Pediatric Practice. R. E. Cooke, editor. McGraw-Hill Book Company, New York. 891.

14. Hohorst, H. J., F. A. Kreutz, and M. Reim. 1961. The oxidation reduction state of the extra mitochondrial DPN/DPNH system in rat liver and the hormonal control of substrate levels in vivo. Biochem. Biophys. Res. Commun. 4 : 163.

15. Hohorst, H. J., F. H. Kreutz, and T. Bücher. 1959. Uber metabolitgehalte und metabolit-konzentrationen in der leber der ratte. Biochem. Z. 332: 18.

16. Heinz, F., W. Lamprecht, and J. Kirsch. 1968. Enzymes of fructose metabolism in liver. J. Clin. Invest. 47: 1826.

17. Pontremali, S., M. Traniello, S. Enser, S. Shapiro, and B. L. Horecker. 1967. Regulation of fructose diphosphatase activity by disulfide exchange. Proc. Natl. Acad. Sci. U.S.A. $58: 286$.

18. Pontremali, S., and E. Grazi. 1968. Gluconeogenesis. In Carbohydrate Metabolism and its Disorders. F. Dickens, P. J. Randle, and W. J. Whelan, editors. Academic Press, Inc., New York. 1: 259.

19. Cahill, G. F., Jr. 1970. Starvation in man. N. Engl. J. Med. 282: 668.

20. Krebs, H. A., T. Gascoyne, and B. M. Norton. 1967. Generation of extra mitochondrial reducing power in gluconeogenesis. Biochem. J. 102: 275.

21. Pagliara, A. S., I. E. Karl, D. C. DeVivo, R. D. Feigin, and D. M. Kipnis. 1972. Hypoalaninemia : a concomitant of ketotic hypoglycemia. J. Clin. Invest. $51: 1440$.

22. Senior, B., and L. Loridan. 1968. Studies of liver glycogenoses, with particular reference to the metabolism of intravenously administered glycerol. N. Engl. J. Med. 279: 958.

23. Perheentupa, J., and N. Hallman. 1969. Hereditary fructose intolerance. In Endocrine and Genetic Diseases of Childhood. L. I. Gardner, editor. W. B. Saunders Company, Philadelphia. 844.

24. Froesch, E. R., H. P. Wolf, H. Baitsch, A. Prader, and A. Labhart. 1963. Hereditary fructose intolerance. An inborn defect of hepatic fructose-1-phosphate splitting aldolase. Am. J. Med. $34: 151$.

25. Muller, W. A., G. F. Faloona, and R. H. Unger. 1971. The effect of alanine on glucagon secretion. J. Clin. Invest. $50: 2215$.

26. Shrago, E., J. W. Young, and H. A. Lardy. 1967. Carbohydrate supply as a regulator of rat liver phosphoenolpyruvate carboxykinase activity. Science (Wash. D. C.). $158: 1572$.

27. Akedo, H., and H. N. Christensen. 1962. Nature of insulin action on amino acid uptake by the isolated diaphragm. J. Biol. Chem. 237: 118.

28. Mallette, L. E., J. H. Exton, and C. R. Park. 1969. Control of gluconeogenesis from amino acids in the perfused rat liver. J. Biol. Chem. 244: 5713.

29. Enser, M., S. Shapiro, and B. L. Horecker. 1969. Immunological studies of liver, kidney and muscle fructose-1,6-diphosphatase. Arch. Biochem. Biophys. 129: 377.

30. Howell, R. R., D. M. Ashton, and J. B. Wyngaarden. 1962. Glucose-6-phosphatase deficiency glycogen storage disease: studies on the interrelationships of carbohydrate, lipid and purine abnormalities. Pediatrics. 29: 553. 